\title{
BUNGA PINJAMAN DALAM PERSPEKTIF KEADILAN \\ (Studi Kasus Bunga Pinjaman di KPRI Nusantara IAIN Walisongo)
}

\author{
Ghufron Ajib, IAIN Walisongo Semarang
}

\begin{abstract}
The subject matter of this study motivated several considerations. The first is that justice is the main major Islamic mission, including social and economic justice. The opponent of justice, namely zhulm (injustice), according to the modernist is raison d'etre of usury probibition, and be decisive for usury legal issues. Second, that since 1990 up to the present system of Shari'ah financial institutions more firmly and growing rapidly with the issuance of Law number 21, 2008 On Islamic Banking and the issuance Minister of Cooperative Regulation 91, 2004 On Guidelines for the Implementation of Activities Cooperative Business Financial Services Shariah. While the savings and loan business unit in KPRI 'Nusantara' since its establishment, in 1973, untill now still running a conventional loan system. In this study, primary data, the loan system and the pattern of calculating interest on savings and loans unit KPRI Nusantara, collected using three methods: participant observation, and interviews with the management and documentat

By using the concept of social justice of John Rawls, the concept maqashid al-Sharia, and the concept of Islamic financial cooperative systems, researchers discuss the issue through three aspects of justice, namely the aspect of contract, the consistency aspect of interest, and justice aspects of cooperatives. Two discussion of this study conclude the absence of justice, namely the aspects of the contract and consistency aspects of interest. The final discussion concludes that there is justice, which is the aspect justice cooperatives.
\end{abstract}

Key Word: Riba, adil, keuangan

\section{Pendahuluan}

Rumusan judul yang menggambarkan pokok persolaan dalam peneltian ini didasarkan pada tiga alasan. Pertama, para pemikir Islam kontemporer dalam membahas persoalan hukum bunga pada umumnya bertumpu pada konsep riba. Dengan memegang teguh konsep riba sebagai

Volume IV/Edisi 1/Mei 2013 
Bunga pinjaman dalam perspektif keadilan

tambahan (al-ziyadab) yang dipungut tanpa imbalan (iwadh) yang diperjanjikan dalam akad dan didasarkan persamaan illat keharaman riba, sebagian pemikir kontemporer memutuskan hukum bunga haram, persis sebagaimana hukum keharaman riba.

Sebagian pemikir lainnya berpendapat bahwa tidak semua tambahan tanpa iwad adalah riba. Dalam pandangan mereka riba adalah tambahan tanpa iwad yang dipungut secara $d$ z $u l m^{1}$ (aniaya, tidak adil). Dengan beralih dari illat jali, yakni tambahan, kepada illat khafi, yakni tambahan yang berssfat zhbulm, maka metode istibsan yang mereka pegangi menghasilkan keputusan bahwa bunga tidak haram, karena bunga dipungut tidak secara dzulm, melainkan secara sukarela berdasarkan akad yang disepakati kedua belah pihak.

Pendapat hukum bunga haram berdasar metode qiyas sangat simple, jelas dan tegas, karena illat tambahan pada bunga adalah fakta yang tidak bisa dimaknai lain,. Hal ini berbeda dengan unsur z̧bulm yang menjadi illat khafi dalam metode istihsan. Sifat kedzaliman ini interpretable dan bisa dipandang dari berbagai sudut yang berbeda.

Berdasarkan metode penalaran istibsan, kahalalan dan keharaman hukum bunga tidak inherent dan tidak pula permanen. Sepanjang unsur keadilan ditegakkan, bunga halal. Sebaliknya, bilamana unsur z̧bulm (ketidakadilan atau kedzaliman) yang terjadi dalam prakteknya maka bunga haram hukumnya. Berdasarkan pertimbangan ini maka dianggap penting melakukan penelitian bunga dari perspektif keadilan, bukan dari perspektif bukum .

Kedua. terkait dengan fungsi lembaga keuangan, terdapat perbedaan instrument akad antara fungsi funding (penghimpunan dana) dan landing (pembiayaan). Dalam lembaga keuangan konvensional funding menggunakan akad titipan (wadi'ah), sedangkan landing menggunakan akad utang (qardh). Maka persoalan hukum bunga pada lembaga keuangan ada pada bunga

1 Para modernis yang berpendapat demikian antara lain Muhammad Abduh, Muhammad Rasyid Ridha, Fazlur Rahman, Muhammad Asad, Said al-Najjar, Abdullah Mun'im al-Namir. Mereka berargumen bahwa raison d' etre pengharaman riba adalah kedzaliman. Pendapat ini mendapat dukungan dari karya-karya ulama klasik, seperti alThabari, al-Zamasysyari, ibn Arabi. Baca Abdullah Saeed, Menyoal Bank Syariab: Kritik Atas Interpretasi bunga Bank BungaKaum Neo-Revivalis, Terj. Arif Maftuhin, Paramadina, Jakarta, Cet III, 2006, hal.60-63 
pinjaman. Sedangkan hukum bunga tabungan sifanya itba' saja, atas dasar satu kesatuan sistim. Berdasarkan pertimbangan ini penulis memfokuskan penelitian pada bunga pinjaman, tidak pada bunga tabungan atau bunga investasi.

Ketiga, sebagai instrumen dari fungsi lembaga keuangan, hukum bunga selalu menjadi topik penting untuk dikaji di tengah masyarakat muslim Hal ini setidaknya disebabkan karena dua faktor mendasar. Pertama faktor fungsional, dimana lembaga keuangan memiliki fungsi fital dalam kegiatan ekonomi negara dan masyarakat, yakni fungsi intermediasi keuangan dengan kegiatan usaha menghimpun dana dan atau menyalurkannya untuk mendukung kegiatan investasi perusahaan, distribusi barang dan jasa, bahkan untuk kegiatan konsumsi. ${ }^{2}$ Fungsi fital ini tidak maksimal ketika masyarakat mayoritas (muslim) mempersoalkan kehalalan bunga. Kedua faktor teologis, yakni sikap ummat Islam yang membutuhkan jaminan halal atas makanan dan sumber-sumber kekayaan. Makanan yang didapat dengan cara yang tidak halal secara bukmiyah dipandang sama haramnya dengan hasil judi

Sosialisasi perkembangan infrastrukur, dan legislasi sistem lembaga keuangan syariah sebagai lembaga keuangan bebas bunga, dalam 20 tahun terakhir ini telah menjadikan lembaga keuangan syariah eksis di tengah-tengah masyarakat dan kedudukannya menjadi setara dengan lembaga keuangan konvensional. Tentu IAIN walisongo telah berperan dalam sosialisasi, riset, maupun penyiapan sumber daya. Peran ini akan menjadi lengkap manakala disertai dengan kebijakan IAIN dalam menata unit simpan pinjam di KPRI Nusantara yang berada di dalam kampus IAIN Walisongo, yang mana sampai sekarang masih menggunakan sistim bunga. Oleh karena itu persoalan bunga pinjaman dalam penelitian ini difokuskan sebagai studi kasus di Koperasi Nusantara IAIN.

Penelitian ini berusaha menjawab persoalan utama "apakah bunga pinjaman di Koperasi Nusantara IAIN walisongo mencerminkan prinsp keadilan?"

2 Andri Soemitro, Bank dan Lembaga Keuangan Syariah, (Jakarta: Kencana Prenada Media Group, 2009), h.29.

Volume IV/Edisi 1/Mei 2013 


\section{Konsep Keadilan dan Sistem Keuangan}

Adil dalam bahasa Indonesia merupakan kata serapan dari bahasa Arab 'adl, yang sepadan dengan kata justice dalam bahasa Inggris. Al-Qur'an menggunakan pengertian yang berbeda-beda bagi kata atau istilah yang bersangkut-paut dengan keadilan. Bahkan kata yang digunakan untuk menggambarkan keadilan juga tidak selalu berasal dari akar kata 'adl. Kata-kata sinonim seperti al-qisth, al-hukm dalam al-Qur'an digunakan dengan pengertian keadilan. ${ }^{3}$ Dalam al-Qur'an kata 'adl berarti kebenaran (alhaqq), keseimbangan dan sikap yang tidak memihak. Secara keseluruhan, pengertian di atas terkait langsung dengan perilaku adil, yaitu penjabaran aspek-aspek keadilan dalam kehidupan sehari-hari.

Adil dapat lebih mudah dimengerti dengan memahami kata negatifnya, lalim, juga merupakan kata serapan dari bahasa Arab zhalim. Yakni laku perbuatan yang meyimpang dari kebenaran, menimbulkan kerugian dan kerusakan. 4

Prinsip keadilan diungkapkan al-Quran dalam hal asal-usul penciptaan, persamaan kedudukan manusia, dan hubungan antar sesama dalam segala aspek kehidupan. Dinyatakan dalam al-Qur'an bahwasanya manusia laki dan perempuan diciptakan dari jiwa yang satu (sama), bahwasanya tidak ada perbedaan kedudukan, diskriminasi, antara manusia, kecuali perbedaan mereka dalam pandangan Allah bedasarkan taqwa dan salah satu pilar utama taqwa itu adalah prilaku adl, “.... karena prilaku adil itu lebih dekat kepada taqwa" (5:8). Adil menjadi syarat bagi pemimpin dan pemerintahan, menjadi syarat proses penegakan hukum, menjadi syarat keabsahan poligami dan lain sebagainya. Bahkan Kepada pihak lawan alQur'an mengharuskan sikap adil, "janganlah permusuban orang (kepadamu) membuat engkau berlaku tidak adil...."(5:8). ${ }^{5}$

\footnotetext{
${ }^{3}$ Penggunaan kata 'adl, qisth, dan bukm, dalam al-Qur'an yang menggambarkan makna keadilan dan konteksnya masing-masing, dapat dibaca dalam Dawam Rahardjo, Ensiklopedi al-Qur'an: Tafsir Sosial dengan konsep-konsep Kunci, Paramadina, Jakarta, cet.II, 2002 m. h.371-380.

${ }^{4}$ Ibid h.395

${ }^{5}$ Baca, Fazlur Rahman, Tema Pokok al-Qur'an, Pustaka, Bandug, Cet. I, 1983 M, hal. 62-67.
} 
Seorang filosuf barat John Rawls ${ }^{6}$ mengembangkan sebuah teori yag disebutnya sebagai "A Teory of Justice" Menurut Rawls, prinsip paling mendasar dari keadilan adalah bahwa setiap orang memiliki hak yang sama dari posisi-posisi mereka yang wajar. Untuk mewujudkan keadilan, struktur konstitusi politik, ekonomi, dan peraturan tentang hak milik haruslah sama bagi semua orang. Atribut-atribut, seperti kemampuan, kekayaan, posisi sosial, pandangan religius dan filosofis, maupun konsepsi tentang nilai, yang membedakan seseoarng dari lainnya harus disingkirkan. Untuk mengukuhkan situasi adil tersebut perlu ada jaminan terhadap sejumlah hak dasar yang berlaku bagi semua, seperti kebebasan untuk berpendapat, kebebasan berpikir, kebebasan berserikat, kebebasan berpolitik, dan kebebasan di mata hukum. ${ }^{7}$

Dalam bukunya a theory of justice ia menjelaskan teori keadilan sosial sebagai the difference principle dan the principle of fair equality of opportunity. Inti the difference principle, dapat diartikan sebagai ketidaksamaan prospek seorang untuk mendapatkan unsur pokok kesejahteraan, pendapatan, dan otoritas. Keadilan menghendaki adanya ketidaksamaan. Demi keadilan, perbedaan sosial dan ekonomis harus diatur agar memberikan manfaat yang lebih besar bagi mereka yang kurang beruntung.

Sementara itu, the principle of fair equality of opportunity ditujukan pada mereka yang kurang mempunyai peluang untuk mencapai prospek kesejahteraan, pendapat dan otoritas. Mereka inilah yang harus diberi perlindungan dan peluang khusus (prioritas). Rawls mengajarkan teori "prinsip keadilan" terutama sebagai alternatif bagi teori utilitarisme 8 sebagaimana dikemukakan Hume, Bentham dan Mill. Rawls berpendapat bahwa dalam masyarakat yang diatur menurut prinsip-prinsip utilitarianisme,

6 John Rawls (lahir pada 21 Februari 1921 di Baltimore, Maryland, Amerika Serikat) adalah filsuf dari Amerika Serikat yang terkenal pada abad ke-20 di dalam bidang filsafat politik. Bukunya yang berjudul "Teori tentang Keadilan" (dalam bahasa Inggris $A$ Theory of Justice) merupakan salah satu teks primer di dalam filsafat politik. Rawls belajar di Universitas Princeton, serta mengajar di Universitas Cornell dan Universitas Harvard.

http://id.wikipedia.org/wiki/John_Rawls

${ }^{7}$ Ibid.

8 Utilitarianisme berasal dari kata Latin utilis, yang berarti berguna, bermanfaat, berfaedah, atau menguntungkan. Utilitarianisme sebagai teori sistematis pertama kali dipaparkan oleh Jeremy Bentham dan muridnya, John Stuart Mill. Utilitarianisme merupakan suatu paham etis yang berpendapat bahwa yang baik adalah yang berguna, berfaedah, dan menguntungkan. http://id.wikipedia.org/wiki/Utilitarianisme, 
Bunga pinjaman dalam perspektif keadilan

orang akan kehilangan harga diri. bahkan perhatian dan layanan demi kemajuan bersama akan lenyap oleh kepentingan pribadi atau golongan. Rawls juga berpendapat bahwa demi kebaikan bersama, yakni kepentingan umum, boleh jadi, diperlukan pengorbanan. Tetapi tidak dapat dibenarkan manakala pengorbanan ini diminta dari orang-orang yang kurang beruntung dalam masyarakat. Pengorbanaan mestilah diperuntukkan bagi mereka yang kurang beruntung.

Lebih lanjut John Rawls menegaskan bahwa program penegakan keadilan yang berdimensi kerakyatan haruslah memperhatikan dua prinsip keadilan, yaitu, pertama, memberi hak dan kesempatan yang sama atas kebebasan dasar yang paling luas seluas kebebasan yang sama bagi setiap orang. Kedua, mampu mengatur kembali kesenjangan sosial ekonomi yang terjadi sehingga dapat memberi keuntungan timbal balik (reciprocal benefits) bagi setiap orang, baik mereka yang berasal dari kelompok beruntung maupun tidak beruntung. ${ }^{9}$

Salah satu konsep fundamental yang menjadi pokok bahasan dalam filasafat hukum Islam adalah konsep maqasid at-tasyri' atau maqasid al-syariah yang menegaskan bahwa hukum Islam disyari'atkan untuk mewujudkan dan memelihara maslahat umat manusia. Konsep ini telah diakui oleh para ulama dan oleh karena itu mereka memformulasikan suatu kaidah yang cukup populer, "dimana ada maslahat, di sana terdapat hukum Allah." Teori maslahat di sini menurut Masdar F. Masudi sama dengan teori keadilan sosial dalam istilah filsafat hukum. ${ }^{10}$

Adapun inti dari konsep maqasid al-syariah adalah untuk mewujudkan kebaikan sekaligus menghindarkan keburukan atau menarik manfaat dan menolak mudarat, istilah yang sepadan dengan inti dari maqasid al-syari'ah tersebut adalah al-maslahat, karena penetapan hukum dalam Islam harus bermuara kepada maslahat.

${ }^{9}$ John Rawls, A Theory of Justice, London: Oxford University press, 1973, diterjemahkan dalam bahasa indonesia oleh Uzair Fauzan dan Heru Prasetyo, Teori Keadilan, (Yogyakarta: Pustaka Pelajar, 2006)

10 Masdar F. Mas'udi, "Meletakkan Kembali Maslahat Sebagai Acuan Syari'ab" Jurnal Ilmu dan Kebudayaan Ulumul Qur'an No.3, Vol. VI Th. 1995. hlm. 97. 
Pembahasan tentang maqasid al-syari'ab secara khusus, sistematis dan jelas dilakukan oleh al-Syatibi dari kalangan Malikiyah. Dalam kitabnya alMuwafaqat, ia menghabiskan lebih kurang sepertiga kitabnya untuk membahas maqasid al-syari'ah. Ia secara tegas mengatakan bahwa tujuan utama Allah menetapkan hukum-hukum-Nya adalah untuk terwujudnya maslahat hidup manusia, baik di dunia maupun di akhirat. Karena itu, taklif dalam bidang hukum harus mengarah pada merealisasikan terwujudnya tujuan hukum tersebut. ${ }^{11}$

Almashlahah yang merupakan inti dari konsep maqabid al-syariah sebagaimana yang dipresentasikan oleh para pemikir hukum Islam , termasuk al-Syatibi, berhenti pada tataran teory yaitu berupa rumusan kaidah-kaidah umum. Kaidah maqashid ini diperlukan untuk membongkar keterikatan pemikiran hukum dari belenggu teks, kecuali dalam persoalan ubudiyah. Konsep maqashid mengantarkan pemikir muslim pada sebuah kenyataan bahwasanya kemaslahatan yang terkandung di dalam legislasi al-Qur'an dan alSunnah tidak menjangkau seluruh tata kehidupan manusia yang terus berkembang. Maka konsep maslahah al-mursalah, sebagai konsep yang dinamis menjadi tanggung jawab setiap generasi dalam keseluruhan disiplin ilmu..

Batasan ruang dan waktu menjadi frame kebijakan maslahat almursalah. Tanpa pengembangan konsep maslahah al-mursalah, wajah hukum Islam, sebagaimana berlangsung pada masa kemunduran, tidak bersinggungan dengan kebutuhan kehidupan nyata. Padahal kebutuhan kehidupan nyata merupakan unsur fundamental dari operasionaliasi konsep maslahah almursalah.

Konsep fungsional uang dalam sistim ekonomi konvensional selain sebagai alat penukaran, juga sebagai capital yang bersifat stock consept. Yakni uang dapat mendatangkan penghasilan. Dalam fungsinya sebagai stock concept, semakin banyak menguasai/memiliki uang dengan sendiri akan menghasilkan pendapatan yang lebih banyak, walaupun tanpa menggunakannya untuk kegiatan usaha. Penghasilan uang sebagai capital ini diperoleh melalui suku bunga.

11 26Al-Syatibi, al-Muwafaqat fi Usul al-Syari'ah (Kairo: Mustafa Muhammad, t.t,) II:4. dan seterusnya

Volume IV/Edisi 1/Mei 2013 
Bunga pinjaman dalam perspektif keadilan

Konsep uang sebagai capital membidani lahirnya konsep the time velue of money, di mana nilai uang bisa bertambah atau berkurang dalam kontek waktu yang diwujudkan dalam bentuk tingkat bunga sebagai parameter harga dari komoditas uang dan tingkat inflasi. Dalam pandangan ini fungsi uang selain dipengaruhi motif transaksi dan motif berjaga-jaga, yakni dalam fungsinya sebagai alat tukar, alat pembayaran, dan alat menyimpan nilai, juga dipengaruhi oleh motif spekulasi. Motif transaksi dan berjaga-jaga ditentukan oleh kebutuhan hidup, sedangkan motif spekulasi dipengaruhi oleh suku bunga.

Tingkat suku bunga ditentukan oleh pola interaksi antara defisit spending unit dan surplus spending unit, yang kemudian menentukan besarnya permintan uang. Dan, yang perlu dipahami, bahwasanya ketika permintaan uang untuk motif spekulasi tinggi, maka ketersediaan uang untuk kebutuhan transaksi berkurang. Kondisi seperti ini dapat mengganggu transaksi atas kebutuhan dasar (konsumtif) juga bisa mengganggu investasi produktif. Akibatnya suku bunga meningkat dan timbul tekanan inflasi. Keduanya memperlemah kondisi ekonomi kelompok lemah. Dampak negative dari fungsi capital ini bertentangan dengan maqashid syariah dan tegolong al-mafsadat yang harus dihindari atau disingkirkan.

Dalam sistim keuangan syari'ah terdapat dua konsep utama tentang uang berdasarkan fungsinya. Pertama, uang sebagai sesuatu yang beredar (flow concept), di mana untuk mendatangkan hasil yang lebih besar uang mesti diputar. Semakin cepat uang beredar, semakin banyak hasil yang didapat melalui kegiatan investasi riil. Jika tidak berputar, nominal uang justru akan berkurang lantaran terkena kewajiban zakat.

Kedua, dalam sistim ekonomi syari'ah, uang sebagai milik publik (money as public goods) bukan semata-mata milik perorangan (privat goods). Karenanya menimbun atau memonopoli uang tidak menghasilkan keuntungan, sia-sia dan dapat mengganggu stabilitas ekonomi.

Demikianlah dalam sistim ekonomi Islam (syari'ah) uang adalah uang, yakni berfungsi sebagai alat untuk motif transaksi (alat pembayaran dan alat tukar-menukar) dan untuk motif berjaga-jaga (sebagai alat untuk menyimpan 
nilai). Dari fungsi inilah, maka difahami sebagai flow concept dan sekaligus sebagai public goods.

\section{Gambaran Umum KPRI Nusantara}

Perkembangan ilmu pengetahuan dan teknologi pada pertengahan abad ke-1812 yang diwarnai berbagai penemuan di bidang teknologi, yang membidani era revolusi industry, melahirkan tata dunia ekonomi baru yang dikenal sebagai sistem ekonomi kapitalisme. Tatanan ekonomi menjadi terpusat pada keuntungan perseorangan, yaitu sekelompok kecil kaum pemodal. Sistem ekonomi kapitalime ${ }^{13}$ pada sisi lain menjadikan masyarakat kebanyakan (ekonomi lemah) sebagai mesin pencetak keuntungan bagi kelompok kapitalis (pemodal) yang menguasi sistim industry (produksi dan distribusi) baik barang maupun jasa.

Ketimpangan ekonoimi yang ditimbulkan sistim kapitalisme ini, menginspirasi kesadaran kelompok ekonomi lemah untuk mendirikan koperasi. Pada tahun 1844 lahirlah koperasi pertama di Inggris yang terkenal dengan nama Koperasi Rochdale di bawah pimpinan Charles Howart. Di Jerman, Frederich Willhelm Raiffeisen dan Hermann Schulze memelopori Koperasi Simpan Pinjam. Di Perancis, muncul tokoh-tokoh koperasi seperti Charles Fourier, Louis Blance, dan Ferdinand Lassalle. Demikian pula di Denmark. Bahkan Denmark menjadi Negara yang paling berhasil di dunia dalam mengembangkan ekonominya melalui koperasi. Kemajuan industri di Eropa akhirnya meluas ke Negara-negara lain, termasuk Indonesia.

Koperasi sebagai badan usaha dalam konteks kehidupan perekonomian bertumpu pada prinsip keangotaan. Prinsip keanggotaan ini berusaha memberdayakan masyarakat (utamanya ekonomi lemah) kepada posisi atau derajat yang tinggi, yakni sebagai anggota yang berhak menentukan kebijakan

12 Revolusi Industri merupakan periode antara tahun 1750-1850 dimana terjadi perubahan secara besar-besaran di bidang pertanian, manufaktur, pertambangan, transportasi, dan teknologi serta memiliki dampak yang mendalam terhadap kondisi sosial, ekonomi, dan budaya di dunia. Revolusi Industri dimulai dari Britania Raya dan kemudian menyebar ke seluruh Eropa Barat, Amerika Utara, Jepang, dan akhirnya ke seluruh dunia. http://id.wikipedia.org/wiki/Revolusi_Industri

${ }^{13}$ Kapitalisme atau Kapital adalah suatu paham yang meyakini bahwa pemilik modal bisa melakukan usahanya untuk meraih keuntungan sebesar-besarnya 
Bunga pinjaman dalam perspektif keadilan

usaha dan berhak atas hasil usaha. Diluar sistem koperasi, kelompok masyarakat dalam setiap kegiatan transaksi konsumtif selalu memberikan keuntungan kepada pihak pemodal, baik dalam transaksi barang dan jasa, lebih-lebih dalam transaski keuangan. Sementara sektor industri dan jalur distribusi dalam ekonomi kapitalis dikuasai oleh para pemodal besar. Lalu di mana posisi kelompok masyartakat ekonomi lemah dalam fungsi industri dan disribusi? Mesin-mesin industri dan distribusi kaum pemodal membutuhkan peran mereka sebagai pekerja, karyawan atau buruh. Ini adalah sebuah peran vital dan riil. Tetapi peran mereka hanya dihargai sebatas upah.

Agaknya kebijakan pengembangan koperasi dapat dipahami sebagai wadah bagi penyatuan dan pengembangan perekonomian masyarkat lemah. Hal ini tercermin dalam konsep koperasi sebagai kumpulan orang, bukan kumpulan modal.

Keberpihakan koperasi terhadap pemberdayaan kelompok ekonomi lemah, dan sekaligus sebagai bentuk perlawanan terhadap sistem ekonomi kapitalis tersurat secara tegas dalam dua prinsip koperasi sebagai berikut ${ }^{14}$ : Pertama, prinsip pembatasan (pengurangan) bunga atas modal. Di dalam koperasi, selain tidak menentukan dominasi penguasaan terhadap kebijakaan, besarnya modal tidak secara otomatis menentukan besarnya pendapatan, kalau tidak didukung dengan peran aktif dalam transaksi di koperasi. Di dalam koperasi, modal pada dasarnya dipergunakan untuk kemanfaatan anggota dan bukan untuk sekadar mencari keuntungan. Oleh karena itu balas jasa terhadap modal juga di batasi, dalam pengertian wajar, tidak melewati suku tabungan yang berlaku di pasar.

Kedua, prinsip pembagian Sisa Hasil Usaha (SHU) sebanding dengan peran aktif anggota dalam transaksi barang atau jasa dalam koperasi, tidak didasarkan semata-mata besarnya modal anggota. Hal demikian ini sebagai perwujudan asas kekeluargaan dan nilai keadilan. Anggota yang modalnya kecil tetapi aktif dalam menggunakan atau membeli produk koperasi berhak atas

\footnotetext{
14 Kedua prinsip tentang pembatasan bunga modal dan sistimm pembagian SHU, ini terdapat dalam sistim koperasi Rochdale, terdapat juga dalam prinsip-prinsip koperasi menurut ICA (International Cooperative Alliance) baca: Pandji Anoraga, Dinamika Koperasi(Jakarta: Rineka Cipta, 2007) h.12-13. Kedua prinsip ini juga terdapat dalam UU. No.25. Th.1992 Tentang Perkoperasian, bac: a pasal 5 ayat 1 pin $\mathrm{c}$ dan $\mathrm{d}$
} 
SHU yang lebih besar dari pada anggota yang modalnya besar tetapi tidak berperan-aktif sama sekali.

Koperasi selain sebagai organisasi ekonomi juga merupakan organisasi pendidikan. Pada prinsipnya kemajuan operasi ditopang oleh tingkat pendidikan anggota yang melahikan kesadaran dan tanggung jawab bersama dalam sistem demokrasi dan tumbuhnya kontrol sosial yang menjadi syarat berlangsungnya pengawasan oleh anggota koperasi. Pada dasarnya tujuan berkoperasi adalah members promotion yang di dalamnya harus melekat members education. Dengan demikian penyelenggaraan pendidikan perkoperasian menjadi inti persoalan dalam pembangunan koperasi. Orientasi penyelenngaraan pendidikan koperasi adalah meningkatkan kemampuan, memperluas wawasan anggota, dan untuk memperkuat solidaritas dalam rangka mewujudkan tujuan berkoperasi .

Koperasi Pegawai Republik Indonesia Nusantara (selanjutnya di Tulis "KPRI Nusantara") dibentuk kurang lebih selang tiga tahun dari peresmian IAIN Walisongo. Peresmian IAIN Walisongo 6 April 1970 ditandai dengan terbitnya Keputusan Mentri Agama RI No.30 dan 31 tahun 1970. Sedangkan Pembentukan KPRI ditandai dengan pengesahan akte pendirian koperasi dan angaran dasar oleh Direktorat Koperasi Propinsi Jawa tertanggal 12 April 1973.

Dalam akte pendirian tersebut, tercatat 5 orang sebagai pendiri. Masingmasing secara berurutan adalah: Djumairi Ahmad, S.H.; Yusuf Ruh Hayat, B.A.; Drs. Haddy Mufa'at Ahmad; Drs. Syamsuddin Yahya, dan Djakfal Heryanto Zubair. Sedangkan Nama koperasi yang dibentuk, tercatat “Koperasi Serba Usaha Karyawan / Dosen IAIN “WALISONGO' dengan nama singkat "KOKIS". Ketika itu IAIN dan koperasi yang dibentuk masih beralamat di Jalan Kimangun Sarkoro No.17 Kec. Semarang Timur, Semarang. Nama koperasi berubah "Koperasi Pegawai Republik, Indoensia (KPRI) Nusantara” sejak 14 september 1973 melalui akte perubahan Anggaran Dasar. Selain perubahan Nama, juga dinyatakan perubahan alamat kantor, dan perubahan distribusi SHU.

Dalam rapat Anggota tahun 2011 yang diselenggarakan pada tanggal 11 maret 2012, disampaikan bahwasanya Unit Simpan Pinjam (USP) 
Bunga pinjaman dalam perspektif keadilan

menempati urutan pertama dalam hal pemasukan keuntungan bagi KPRI Nusantara. Prioritas alokasi modal untuk unit simpan pinjam didasarkan beberapa pertimbangan, anatara lain sebagai berikut:

- Anggota banyak yang membutuhkan jasa simpan pinjam

- Mendatangkan keuntungan berupa jasa pinjaman yang pasti

- Data pendukung kegiatan usaha terkontrol dan transparam .

- Resiko kemacatan cicilan nyaris tidak ada

Untuk mendukung ketertiban kegiatan usaha USP, melalui Rapat Anggota Tahunan pengurus mengambil beberapa kebijakan sebagaimana berikut ini;

Pertama: memisahkan pelayanan USP dari pelayanan unit usaha yang lain . Hal ini dimaksudkan untuk memenuhi ketentuan PP. No. 9 Tahun 1995, pasal 12 ayat (1). Sebetulnya PP. tersebut secara utuh tidak hanya menghendaki pemisahan pelayanan, tetapi pemisahan pengelolaan secara utuh meliputi tanggung jawab pelayanan, pengaturan sistim, biaya operational dan sistim pembagaian SHU.

Kedua:Dalam aspek permodalan pengurus mengambil kebijakan meningkatkan jumlah simpanan wajib dan simpanan suka rela. Untuk anggota PNS Masing-masing golongan ada kenaikan sebesar Rp 5000. Sedangkan anggota dari pegawai Hononer, kenaikan simpanan wajb sebesar Rp. 2000. Untuk simpanan suka rela, koperasi menyediakan formulir persetujuan. Terdapat empat pilihan produk simpanan sukarela, yaitu Tabungan/Simpanan Pendidikan, Tabungan/Simpanman Idul Fitri, Tabungan/Simpanan Qurban dam Tabungan/Simpanan Haji.

Ketiga: Meningkatkan jumlah maksimal pinjaman dari Rp. 25.000.000. menjadi Rp.50.000.000. dengan masa angsuran pinjaman 10 kali, 15 kali, dan 20 kali. Realisasi pinjaman didasarkan pada standar kecukupan gaji, yakni maksimal sebesar $1 / 3$ dari Take home pay dari gaji masing-masing anggota.

Keempat: Melibatkan pihak asuransi untuk memberikan jaminan terhadap peminjam manakala terjadi kematian, dalam hal seluruh resiko pinjaman yang belum dibayar ditanggung oleh pihak asuransi. 
Kelima: Memungut jasa pinjaman sebesar 1,5\% yang dibayarkan setiap bulan beserta angsuran pokok. Misalnya pinjaman sebesar Rp. 10.000.000. diangsur selama 20 bulan. Maka setiap bulan peminjam mengangsur pokok sebesar 10.000.000/20 = Rp. 500.000. ditambah jasa pinjaman setiap bulan sebesar 1.5\% x Rp.10.000.000 = Rp.150.000.

Keenam: Memungut denda 1x jasa jika peminjam menutup/melunasi hutangnya sebelum jatuh bulan tempo. Misalnya jika anggota meminjam sebesar Rp.10.000.000, diangsur selama 20 bulan. Apabila peminjam tersebut bermaksud melunasi atau menutup pinajaman sebelum bulan ke 20, maka yang bersangsukan dikenai denda atau charge sebesar Rp. 150.000.

Ketujuh : Pembagian SHU dari unit simpan pinjam dilaksanakan secara adil dan proporsional (berimbang) ${ }^{15}$ dengan pola pembagaian $40 \%$ untuk porsi modal dan 60\% untuk transaksi pinjaman. Anggota yang melakukan transaksi pinjaman disebut sebagai anggota aktif. Sedang anggota yang tidak melakukan transaksi pinjaman dalam setahun disebut sebagai anggota pasif. Anggota aktif mempunyai dua hak atas SHU, yakni hak SHU atas simpanan sebesar 40\% dan hak SHU atas transaksi sebesar 60\%. Sedang anggota yang tidak aktif berhak atas SHU modal saja.

Sejumlah kebijakan tersebut, berdasarkan keterangan ketua pengurus koperasi, merupakan hasil kesepakatan anggota yang diputuskan melalui mekanisme RAT, yang selalu membuka kesempatan anggota untuk mengoreksi ulang kebijakan tersebut.

\section{Pembahasan}

Praktek pinjam-meminjam di KPRI Nusantara cenderung bercorak kekeluargaan dengan prosedur yang sangat simpel. Artinya pihak koperasi berusaha semaksimal mungkin untuk mengabulkan permohonan pinjaman anggota dengan spirit menolong dan mempercayai.

\footnotetext{
15 Pembagaian SHU ini merujuk pada ketentuan PP. No.9 Tahun 1995 pasal 13 ayat (1) point a : "Sisa Hasil Usaha yang diperoleh Koperasi Simpan Pinjam setelah dikurangi dana cadangan, dipergunakan untuk (a) dibagikan kepada anggota secara berimbang berdasarkan jumlah dana yang ditanamkan sebagai modal sendiri dan nilai transaksi.
} 
Pada dasarnya setiap anggota berhak untuk mengajukan permohonan pinjaman dan berhak dikabulkan permohonannya, tanpa persyaratan administrasi apapun. Bahkan anggota yang pinjamannya belum lunas sekalipun juga berhak mengajukan pimjaman dengan ketentuan kesanggupan untuk melunasi pinjaman terdahulu ketika pencarian, dengan sistim memotong nominal pinjamaan. Tidak ada prosedur yang rumit dan tidak ada tata tertib yang memberatkan anggota yang hendak meminjam. Kenyaatan seperti ini sangat berbeda sekali dengan pengajuan permohonan di bank atau lembaga kekuangan lainnya.

Proses permohonan sampai pencairan pinjaman secara garis besarnya terdiri dari dua prosedur, yaitu prosedur pengajuan permohonan pinjaman dan prosedur pencairan.

\section{Pengajuan Permohonan Pinjaman}

Sebelum pengajuan permohonan pinjaman biasanya anggota yang bersangkutan berusaha mendapatkan informasi lebih rinci tentang besarnya plafon pinjaman, masa angsuran, besarnya jasa pinjaman dan tentang rincian angsuran perbulan. Pengurus sesungguhnya telah melampirkan hal-hal yang terkait dengan informasi sistim peminjaman tersebut, pada bagian akhir buku laporan Rapat Anggota Tahunan. Dengan cara demikian maka semua anggota dianggap telah mengetahui perihal sistem peminjaman di USP KPRI Nusantara.

Untuk keperluan pemohonan peminjaman, USP telah menyediakan form permohonan pinjaman uang. Form tersebut ditujukan kepada Ketua KPRI Nusantara IAIN Walisongo. Secara garis besarnya berisi tentng identitas pemohon, alasan/kepentingan mengajukan pinjaman, dan sistim pengembaliannya akan dibayar melalui potong gaji. Selain identitas pemohon, berikuti ini adalah materi pengajuan permohonan pinjaman.

"Berhubung ada keperluan untuk.......................... maka bersama ini saya mengjukan permohonan pinjam uang kepada KPRI "Nusantara" sebesar Rp...................................) Adapun pengembaliannya saya bersedia dipotong........... kali lewat 
gaji sesuai dengan peraturtan yang berlaku di KPRI "Nusantara Aiain Waliksongo Semarang."

Sebagaimana terbaca dalam kutipan tersebut diatas, form permohonan pinjaman tidak memuat hal-hal berikut ini.

1) Tidak memuat pernyataan bahwa pihak pemohon telah mengetahui tata tertib dan aturan yang berlaku di dalam sistim peminjaman di koperasi Nusamtara

2) Tidak memuat aturan atau pernyataan kesediaan membayar jasa pinjaman $1.5 \%$

3) Tidak memuat aturan atau pernyataan kesediaan mengikuti asuransi jiwa PT. Jasa Lindung.

4) Tidak memuat aturan atau pernyataan kesediaa0 n membayar denda/charge.

Secara normative beberapa aturan atau pernyataan kesedian tersebut perlu dinyatakan dalam materi permohonan, karena berkaitan dengan kewajiban atau beban yang harus dipenujhi oleh oleh peminjam.

\section{Pencairan Pinjaman}

Prosedur pencairan pinjaman di USP Koperasi Nusantara ditandai dengan dua hal. Pertama, penyerahan uang pinjaman oleh petugas USP kepada peminjam dan penyerahan bukti (kwitansi) penerimaan uang oleh peminjam kepada petugas USP. Kedua, penandatanganan surat penyataan bermaterai Rp.6000 oleh pihak peminjam. Selain berisi tentang identitas personal peminjam, surat pernyataan tersebut berisi beberapa point pernyataan kesediaan peminjamn sebagaimana berikut ini

1. Saya telah menerima pinjaman uang dari KPRI Nusantara IAIN Walisongo sebesar Rp. ..................................)

2. Bersedia mengangsur pinjaman tersebut dengan dipotong gaji ...kali.

3. Bersedia mengikuti Asuransi jiwa dengan ketentuan yang berlaku 
Bunga pinjaman dalam perspektif keadilan

4. Bersedia mentaati peraturan yang berlaku di KPRI Nusantara IAIN Walisongo.

Dalam bahasa fiqh muamalah, pernyataan sebagaimana yang dikutip diatas adalah sebuah qabul. Katika penyataan ijab tidak dinyatakan secara verbal, maka pernyataan qabul, sepanjang tidak ada perlawanan, dianggap mencerninkan materi ijab. Segala hal yang terkait langsung dengan obyek akad harus dinyatakan secara jelas dan tegas dalam ijab dan qabul. Substansi ojek akad adalah hak dan kewajiban masing-masing. Jika obyek akad tidak dinyatakan secara jelas maka akad tersebut bisa dipandang cacat, tidak memenuhi syarat rukun akad..

Dalam form ijab- qabul diatas tidak memuat pernyataan tentang jasa pinjaman sebesar 1,5\% dan besaran nominal jasa setiap bulannya. Juga tidak memuat pernyataan tentang denda atau charge. Yang ada adalah pernyataan kesediaan mentaati peraturan yang berlaku di KPRI Nusantara IAIN Walisongo. Pernyataan ini bersifat umum dan bercorak kwalitatif. Sedangkan imbal jasa pinjaman sebesar 1,5\% dan besaran nominalnya perbulan bercorak kwantitatf yang tidak bisa diungkapkan secara kwalitatif. Jadi imbal jasa pinjaman seharusnya dinyatakan dalam ijab.

Terkait dengan fungsi Unit Simpan Pinjam (USP) sebagai lembaga keuangan, terdapat perbedaan instrumen akad antara fungsi funding (penghimpunan dana) dan landing (pembiayaan). Dalam lembaga keuangan konvensional, termasuk USP, kegiatan funding menggunakan akad titipan (wadi'ab), sedangkan kegiatan landing menggunakan akad utang (al-qardb).

Mendistribusikan sebagian keuntungan kepada pemilik dana (tabungan, simpanan) melalui akad wadiah baik berupa hadiyah maupun berupa bagi hasil tidak dipersoalkan dalam hukum Islam ${ }^{16}$. Dalam koperasi, tujuan penitipan modal adalah untuk berserikat melalui instrumen akad musyarakah untuk berbagi hasil secara kongkrit. Hak atas hasil usaha melalui akad sirkah ini tidak ada persoalan dalam hukum Islam, karena mencerminkan prinsip keadilan. Besar kecilnya keuntungan yang didapat melalui mekanisme

\footnotetext{
${ }^{16}$ Ibn Rusyd al-Andalusiy, Bidayat al-Mujtabid, Juz II, Usaha Keluarga, Semarang, tt, hal. 233.
} 
pembagian sisa hasil usaha sangat bergantung pada kinerja koperasi dan partisipasi anggota.

Hal ini berbeda dengan memungut tambahan (bunga) melalui akad qardh dimana mayoritas literature fiqh memandangnya sebagai bagian dari paraktek riba. ${ }^{17}$. Maka persoalan di dalam usaha simpan pinjam koperasi ada pada bunga pinjaman. Sedangkan hasil usaha yang dibagikan kepada anggota koperasi pada dasarnya adalah adil dan halal. Tetapi karena terkait dalam satu kesatuan sistem usaha, status hasil usaha tersebut itba' (bergantung) pada status bunga pinjaman koperasi.

Sekalipun dinyatakan dengan istilah " jasa pinjaman", imbalan sebesar $1,5 \%$, secara lugas (obyektif) jasa pinjaman tersebut adalah bunga ${ }^{18}$ berdasarkan tiga alasan sebagai berikut.

Pertama, karena objek transaksinya adalah uang. Sebagaimana telah disampaikan dalam bab II tentang pengertian dan fungsi uang, Sekiranya objek transaksi berupa barang atau manfaat, maka harga atau imbalan yang harus dibayar tergolong fee, jasa atau ujrah. Penggunaan istilah imbalan untuk sebuah jasa pinjaman uang tidak tepat. Istilah yang tepat adalah bunga. ${ }^{19}$ Sebagaimana bunga didefinisikan sebagai imbal jasa atas pinjaman uang.. Jumlah pinjaman tersbut disebut "pokok utang" (principal). Persentase dari pokok utang yang dibayarkan sebagai imbal jasa ( bunga) dalam suatu periode tertentu disebut "suku bunga"

Kedua, karena format transaksinya adalah pinjaman, sebagaimana terdapat dalam qabul: "saya menyatakan telah menerima pinjaman". Harga atas tt, hal.304.

${ }^{17}$ Abu Ishaq as-Syairoziy, al-Muhadzdzab fi Figh al-Imami al-Syafi'I, Juz I, Toha Putra, Semarang,

18 Fatwa MUI no.01 tahun 2004 memutuskan dua hal penting: 1. Praktek pembungaan uang saat ini telah memenuhi kriteria riba yang terjadi pada jaman Rasulullah SAW, Ya ini Riba Nasiah. Dengan demikian, praktek pembungaan uang ini termasuk salah satu bentuk Riba, dan Riba Haram Hukumnya. 2. Praktek Penggunaan tersebut hukumnya adalah haram,baik di lakukan oleh Bank, Asuransi, Pasar Modal, Pegadian, Koperasi, Dan Lembaga Keuangan lainnya maupun dilakukan oleh individu.

${ }_{19}$ Bunga didefinisikan sebagai imbal jasa atas pinjaman uang. Imbal jasa ini merupakan suatu kompensasi kepada pemberi pinjaman atas manfaat kedepan dari uang pinjaman tersebut apabila diinvestasikan. Jumlah pinjaman tersbut disebut "pokok utang" (principal). Prosentase dari pokok utang yang dibayarkan sebagai imbal jasa ( bunga) dalam suatu periode tertentu disebut "suku bunga" http://id.wikipedia.org/wiki/Suku_bunga 
Bunga pinjaman dalam perspektif keadilan

pinjam uang atau utang lebih populer disebut sebagai bunga, dari pada jasa atau ongkos sewa

Ketiga, karena imbalan tersebut dinyatakan dengan prosentasi suku bunga atas jumlah pinjaman, tidak dinyatakan dengan nominal atas nilai guna pinjaman yang bersifat kongkrit.

\section{Bunga Pinjaman Dalam Konteks Keadilan Akad}

Salah satu unsur utama (syarat) berakad adalah iradah aqdiyah (kehendak berakad). Ijab qabul yang merupakan shighat 'aqad merupakan ungkapan verbal yang mencerminkan kehendak masing-masing. Adapun substansi dari ijab qabul tesebut adalah al-ridha (rela). ${ }^{20}$ Kerelaan tidak cukup hanya terwujud ketika berlangsung ijab qabul, tetapi harus juga terwujud sesudahnya. Munculnya gharar, tadlis, 'aib sesudah ijab qabul dapat menciderai kerelaan, karena menimbulkan kerugian. Pihak yang dirugikan berhak membatalkan akad melalui khiyar. Substansi ridha yang merupakan kondisi saling diuntungkan, atau setidaknya tidak ada pihak yang dirugikan adalah wujud nyata keadilan dalam berakad.

Aspek manfaat atau nilai guna uang pinjaman sesungguhnya bersifat relative, karena manfaat atau nilai guna uang sesungguhnya adalah sebagai alat untuk memenuhi kegunaan obyektif, yakni kebutuhan konsumtif dan kebutuhan investasi. Dalam Pendistribusian nilai kegunaaan pinjaman apakah menghasilkan untung besar, tidak menghasilkan keuntungan atau bahkan menimbulkan kerugian adalah persoalan lain yang tidak terkait dengan pinjaman. Pemungutan bunga atas transaksi pinjaman berarti menyatukan dua hal yang tikak terkait, yakni transaksi pinjaman dan transaksi investasi. Demikianlah, pola perimbangan antara resiko bunga yang ditanggung peminjam dan nilai kegunaan pinjaman tidak mencermikan pola perimbangan antara hak dan kewajiban. Pihak peminjam seharusnya hanya berhak atas pengembalian pinjaman tanpa penambangan hasil. Sebab akadnya adalah pinjaman bukan akad investasi.

${ }^{20}$ Ghufron Ajib Mas'adi, Fikih Muamaah Kntekstual, Raja Grafindo, Jakarta, 2002, cet. I, hal. 96. 
Sering dipahami bahwa bunga pinjaman yang dipungut oleh koperasi adalah imbalan atas jasa dari sebuah sistim keuangan. Sebagian bunga untuk membiayai operasional sistim lembaga koperasi simpan pinjam, sisanya didistribusikan kepada anggota sebagai keuntungan atau hasil usaha. Demikianlah kurang lebih dasar pandangan yang menyatakan bahwa bunga pinjaman adalah sebuah keniscayaan dalam lembaga tijarah (bisnis). Pandangan seperti ini terbangun dari sistim ekonomi kapitalis, di mana uang selain difungsi alat sekaligus sebagai obyek investasi.

Persoalannya terletak apakah instrumen bunga pinjaman tersebut mencerminkan prinsip keadilan. Bunga, sewa, upah dan laba, sebagai instrument profite bersifat kongkrit dan jelas, baik dalam bentuk nominal maupun dalam bentuk prosentase. Dalam konsep akad, obyek transaksi yang dibayarkan dengan instrument harga tertentu harus juga kongkrit ${ }^{21}$ dan jelas. Berbeda dengan bunga, instrument sewa dibayarkan atas manfaat kongkrit suatu benda. Demikian juga upah dibayarkan atas kerja yang kongkrit. Begitupun laba (atau margin keuntungan) dalam jual beli dibayarkan dalam bentuk kelebihan dari harga pokok atas obyek kongkrit dalam transasksi jual beli.

Uang sama sekali tidak mempunyai manfaat konsumtif bagi manusia, melainkan hanya sebatas alat untuk membeli (membayar) barang-barang atau jasa konsumtif yang dibutuhkmannya. Dengan demikin maka kegiatan usaha (produksi dan distribusi) harus dipahami sebagai segala bentuk dan jenis kegiatan yang memproduksi atau menyediakan barang- barang atau jasa yang dibutuhkan untuk memenuhi kebutuhan konsumtif manusia. Dalam sistem ekonomi kapitalis sekalipun, investasi uang sebagai sebuah usaha adalah nonsense. Dalam hal ini uang sebatas sarana nilai hiutung yang harus diinvestasikan dalam kegiatan produksi barang atau jasa. Tanpa kegiatan usaha sektor riil ini, uang sama sekali tidak memiliki nilai investasi.

Untuk memenuhi kebutuhan konsumsi, uang jelas tidak menghasilkan sesuatu apapun. Oleh karena itu pungutan bunga pinjaman konsumtif sangat

${ }^{21}$ Dalam fiqh mumalah istilah yang diapakai adalah "mujud”, sebagaian bagian dari syarat obyek akad, maksudnya obyek akan harus wujud, baik dalam bentuk wujudl material maupun wujud dalam bentuk konseptuan. Baca Ghufron A, Mas'adi, Fiqh Muamalah Kontekstual (Jakarta: PT. RajaGrafindo Persada, 2002), h.86 
dominan unsur eksploitasinya. Peminjam dipungut bunga, atas sejumlah pinjaman yang sama sekali tidak menghasilkan keuntungan pada dirinya. Solusi yang adil adalah dengan pola pembiyaan jual beli yang dalam sistem lembaga keuangan syari'ah disebut dengan istilah bai al-murbahah, yakni pola pembiayaan konsumtif melalui pengadaan barang-barang yang dibutuhkan anggota melalui instrumen transaski jual-beli dengan harga pokok ditambah keuntungan yang disepakati oleh kedua belah pihak. Melalui transaski bai' murabahah ini koperasi mendapat laba dari usaha yang real yakni pengadaan (pembelian) barang dan menjualnya kepada anggota. Dalam pola transaski bai' murabahah anggota lebih diuntungkan. Selain mendapat point SHU, anggota juga mendapat harga pokok yang lebih murah karena hanya menaggung satu beban, yakni beban irbah atau margin keuntungan. Sedang dalam transaksi konvensional anggota menanggung dua beban, yakni bunga dan keuntungan pihak penjual.

Ketidakadilan bunga tidak hanya terdapat dalam pinjaman konsumtif saja, tetapi juga dalam pinjaman investasi. Sebab, bunga besrsifat pasti dan kongkrit sedangkan hasil investasi tidak pasti. kegiatan produksi dan distribusi yang didanai oleh modal pinjaman bisa saja tidak menghasilkan keuntungan bahkan bisa merugi,. Sekalipun demikian bunga tetap dipungut. Yang demikian ini jelas menunjukkan pola hubungan sistem ekonomi kapitalisme yang tidak adil. Pola hubungan yang mencerminkan keadilan adalah pola transaskis mudharabah (bagi hasil) di mana pihak shabibul mal hanya berhak atas keuntungan dari hasil usaha riil yang dilakukan oleh pihak mudharib (pengelola). Kedua belah pihak ada dalam posisi yang setara dalam pola kemitraan (berserikat) untuk mencapai tujuan bersama yakni, berbagi hasil.

Keadilan di dalam konsep akad investasi mestilah dibangun dari dan dengan mendudukkan posisi masing-masing pihak yang terkait dalam transaksi pada posisi yang setara (adil). Partisipasi masing-masing pihak dalam kegiatan usaha investasi menjadi dasar penentuan keadilan dalam berbagi hasil. Bunga dalam transaki kredit, sekalipun dalam konteks investasi, sejak awal mendudukkan masing-masing pihak pada posisi yang tidak adil. Pemodal diposisikan lebih tinggi dan tidak menanggung resiko. Sedangkan peminjam dalam posisi yang rendah yang harus menanggung segala resiko. 
Mencari keuntungan (profite orientation) melalui aktifitas investasi hanyalah satu sisi dari kehidupan manusia. Sisi lainnya adalah aktifitas sosial yang didasari sikap kepedulian dan sikap keberpihakan terhadap kelompok masyarakat yang kurang beruntung. Kedua sisi kehidupan ini harus ada demi kehidupan yang berkeadilan sosial. Mengorientasikan profite atau membisniskan akad (kontrak, perjanjian) sosial adalah sebuah pemaksaan fungsional, sekalipun melaui instrumen akad. Yang demikian ini merupakan enter point dari praktek ekploitasi pihak pemodal terhadap pihak lain melalui transaksi pinjaman berbunga. Sebab, pinjaman (utang) sesungguhnya adalah pola transaski non profite sebagai keberpihakan terhadap kelompok ekonomi lemah demi tercapainya keadilan sosial dalam bidang ekonomi.

Dalam konteks keadilan sosial ekonomi ini, menurut konsep the principle of fair equality of oppurtunity John Rwls, pihak yang kurang mampu diberi peluang untuk mencapai prospek kesejahteraan, pendapatan dan otoritas. Mereka inilah yang harus diberi perlindungan khusus (Prioritas). Menurutnya, konsekwensi dari kehidupan bersosial adalah keharusan berkurban demi kepentingan umum. Tetapi tidak dapat dibenarkan bahwa pengorbanan ini diminta dari orang-orang yang kurang mampu untuk kelompok pemodal.

Lebih lanjut John Rawls menegaskan bahwa program penegakan keadilan yang berdimensi kerakyatan haruslah memperhatikan dua prinsip keadilan. Pertama, memberi hak dan kesempatan yang sama atas kebebasan dasar yang paling luas seluas kebebasan yang sama bagi setiap orang. Kedua, mengatur kesenjangan sosial ekonomi yang terjadi sehingga dapat memberi keuntungan timbal balik (reciprocal benefits) bagi setiap orang, baik mereka yang berasal dari kelompok beruntung maupun tidak beruntung. ${ }^{22}$

Larangan terhadap praktek pemungutan bunga atas tansaksi utangpiutang, dalam syariat Islam, merupakan harga minimal dari proyek besar Islam dalam menciptakan tatanan kehidupan sosial-ekonomi secara adil, sebagaimana disampaikan oleh John Rawls. Harga Maksimalnya adalah

22 John Rawls, A Theory of Justice, London: Oxford University press, 1973, diterjemahkan dalam bahasa indonesia oleh Uzair Fauzan dan Heru Prasetyo, Teori Keadilan, (Yogyakarta: Pustaka Pelajar, 2006) 
Bunga pinjaman dalam perspektif keadilan

perintah kewajiban membayar zakat dan shadaqah (charity), menyembelih binatang kurban, dan lain sebagainya.

Terciptanya tatanan kehidupan ekonomi-sosial yang berkeadilan yang berbingkai semangat keberpihakan dan kepedulian terhadap kelompok masyarakat lemah, sebagaimana disampaikan dalam konsep keadilan sosial John Rawls, sesungguhnya merupakan maqashid al-syari'ab dari sejumlah larangan keras al-Qur'an terhadap praktek riba Jahiliyah, perintah al-Qur'an terhadap kewajiban zakat dan shadaqah, seruan ajaran aran Islam terhadap tolong menolong dan seruan Islam terhadap prilaku adil dan kebajikan. Semua ini menjadi penguat bahwa pemungutan bunga melalui transaski pinjaman (utang-piutang) bertentangan dengan proyek besar Islam dalam membangun keadilan sosial ekonomi.

\section{Konsistensi Prosentasi bunga dan Nominalnya}

Melalui mekanisme RAT, pengurus KPRI Nusantara mengambil kebijakan memungut jasa pinjaman sebesar 1,5\% yang dibayarkan setiap bulan beserta angsuran pokok. Misalnya pinjaman sebesar Rp. 10.000.000. diangsur selama 20 bulan. Maka setiap bulan peminjam mengangsur pokok sebesar $10.000 .000 / 20=$ Rp. 500.000. ditambah jasa pinjaman setiap bulan sebesar 1.5\% x Rp.10.000.000 = Rp.150.000. Tentang bunga pinjaman sebesar 1,5\% perbulan serta besar nominalnya telah dimaklumkan dalam bentuk lampiran pada buku laporan pertanggungjawaban pengurus,. Lampiran tersebut anatara lain isisnya sebagai berikut .

\begin{tabular}{|l|l|l|l|}
\hline $\begin{array}{l}\text { Jumlah } \\
\text { pinjaman }\end{array}$ & $\begin{array}{l}\text { Administrasi } \\
\text { perbulan } 1,5 \%\end{array}$ & Jumlah pinjaman & $\begin{array}{l}\text { Adminitrasi } \\
\text { perbulan1,5\% }\end{array}$ \\
\hline Rp. 1.000 .000 & Rp. 15.000 & Rp. 30.000 .000 & Rp. 450.000 \\
\hline Rp. 5.000 .000 & Rp. 75.000 & Rp. 35.000 .000 & Rp. 525.000 \\
\hline Rp. 10.000 .000 & Rp. 150.000 & Rp. 40.000 .000 & Rp. 600.000 \\
\hline Rp. 15.000 .000 & Rp .225.000 & Rp. 45.000 .000 & Rp. 675.000 \\
\hline Rp. 20.000.000 & Rp .300.000 & Rp. 50.000 .000 & Rp. 750.000 \\
\hline Rp. 25.000.000 & Rp .375.000 & Rp. 60.000 .000 & Rp. 900.000 \\
\hline
\end{tabular}


Dalam tabel tersebut digunakan istilah administrasi 1,5\%, sedang pada kesempatan lain digunakan istilah jasa pinjaman. Mengenai penggunaan istilah jasa simpanan adalah tidak tepat, dengan alasan sebagaimana telah disampaikan pada sub bab sebelumnya. Lebih tidak tepat lagi penggunaan istilah biaya administrasi. Karena istilah ini tidak memberikan pengertian yang jelas.

Prosentase bunga sebesar 1,5\% perbulan dan besaran nominalnya sama sekali tidak dinyatakan dalam surat permohonan pinjaman, juga tidak dinyatakan surat pernayataan transaski, sebagaimana kedua suratvtersebut telah dimkutip pada bab III.

Dalam form qabul yang disampaikan melalui surat pernyataan pihak peminjam tidak memuat pernyataan tentang jasa pinjaman sebesar $1,5 \%$ dan besaran nominal jasa setiap bulannya. Juga tidak memuat pernyataan tentang denda atau charge. Yang ada adalah pernyataan kesediaan mentaati peraturan yang berlaku di KPRI Nusantara IAIN Walisongo. Perenyataan ini bersifat umum dan bercorak kwalitatif. Sedangkan imbal jasa pinjaman sebesar 1,5\% dan besaran nominalnya perbulan bercorak kwantitatf yang tidak bisa diungkapkan secara kwalitatif. Jadi imbal jasa pinjaman harus dinyatakan dalam ijab baik dalam prosentasi dan dalam bentuk besaran nominalnya. Demikian juga tentang kesediaan diberikan sanksi atas percepatan perlunasan pinjaman sebesar 1x jasa pinjaman.

Kata kunci untuk membahas praktek bunga pinjaman di KPRI "Nusantara" adalah Penyimpangan atau ketidak-konsistenan antara prosentase suku bunga dan besaran nominalnya. Misalnya aplikasi pinjaman sebesar Rp. 1.000.000 (satu juta Rupiah), diangsur selama sepuluh bulan, maka pinjaman pokok yang harus diangsur adalah sebesar Rp. 100.000. Adapun besarnya nominal bunga perbulan menurut perhitungan pengurus koperasi adalah sebesar Rp. 15.000. Jumlah nominal ini di dapat dari perkalian suku bunga 1,5\% terhadap jmumlah pinjaman pokok sebesar Rp. 1.000.000.,

Setiap pembayaran angsuran pokok sebesar Rp. 100.000 setiap bulan terjadi sesungguhnya terjadi pengurangan pokok pinjaman sebesar angsuran tersebut. Tetapi pengurangan pokok pinjaman tersebut tidak berpengaruh pada besaran nominal bunga yang nominalnya tidak berubah dari awal sampai 
Bunga pinjaman dalam perspektif keadilan

akhir, yakni Rp.15.000. Jika demikian maka prosentasi bunga atas sisa pinjaman mengalami kenaikan atau penggelembungan. Sebagaimana dapat dlihat dalam analisis table berikut ini

\begin{tabular}{|l|l|l|l|l|}
\hline Angsuran & Sisa pinjaman & Angsuran pokok & Nominal bunga & Prosentase riil \\
\hline I & Rp. 1.000 .000 & Rp. 100.00 & Rp.15.000 & $1,5 \%$ \\
\hline II & Rp. 900.000 & Rp. 100.00 & Rp.15.000 & $1,66 \%$ \\
\hline III & Rp. 800.000 & Rp. 100.00 & Rp.15.000 & $1,87 \%$ \\
\hline IV & Rp. 700.000 & Rp. 100.00 & Rp.15.000 & $2,14 \%$ \\
\hline V & Rp. 600.000 & Rp. 100.00 & Rp.15.000 & $2,5 \%$ \\
\hline VI & Rp. 500.000 & Rp. 100.00 & Rp.15.000 & $3 \%$ \\
\hline VII & Rp. 400.000 & Rp. 100.00 & Rp.15.000 & $3,75 \%$ \\
\hline VIII & Rp. 300.000 & Rp. 100.00 & Rp.15.000 & $5 \%$ \\
\hline IX & Rp. 200.000 & Rp. 100.00 & Rp.15.000 & $7,5 \%$ \\
\hline X & Rp. 100.000 & Rp. 100.00 & Rp.15.000 & $15, \%$ \\
\hline & Jumlah & Rp.1.000.000 & Rp.150.000 & \\
\hline
\end{tabular}

Dari tabel ilustrasi diatas kita dapat melihat bahwa angsuran yang dibayar setiap bulan selalu bernilai Rp. 115.000. Angsuran ini terdiri dari angsuran pokok Rp. 100.000 dan bunga sebesar Rp. 15.000 . Dengan membayar angsuran pokok berarti pokok pinjaman berkurang sebesar Rp. 100.000 setiap bulannya. Pada kolom prosentasi bunga terlihat prosentasi bunga selalu bertambah besar (menggelembung) dari angka 1,5\% menuju angka 15\% dalam jangka waktu yang sangat pendek, yakni 10 bulan. Jika diangsur dalam 20 bulan, maka prosentasi bunga pada angsuran ke 20 naik (berlipat) menjadi 30\%. Jika diangsur 40 kali dalam 40 bulan, prosentasi bunga pada angsuran terakhir sebesar 60\%. Dan apabila diangsur 50 kali dalam 50 bulan, prosentasi bunga pada angsuran terakhir menggelembung sebesar 75\%.

Kenaikan prosentasi bunga yang terus bergerak setiap bulan hingga mencapai 15\% pada angsuran kesepuluh, 30\% pada angsuran keduapuluh, 60\% pada angsuran keempatpuluh $75 \%$ pada angsuran kelimapuluh, dan seterusnya, tidak ada lain yang bisa dikatakan kecuali ini adalah praktek 
ekploitasi sistim bunga. Semakin kebelakang keuntungan koperasi semakin besar ${ }^{23}$ sebanding dengan besarnya kerugian yang ditanggung pihak peminjam.

Dengan demikian, pemakluman bunga sebesar $1,5 \%$ perbulan, sebagaimana di maklumkan dalam table pinjaman dan angsurannya, yang tidak disertakan dalam pernyataan qabul adalah gharar, yakni tipu daya. Tidak ada gharar dalam transaksi yang menguntungkan kedua pihak. Demiakian juga tidak ada gharar yang merugikan kedua pihak. Gharar selalu menguntungkan satu pihak dengan menjadikan pihak lain sebagai korban yang menanggung kerugian. ${ }^{24}$

Harusnya besarnya bunga dinyatakan secara jelas dalam rumusan ijabqabul. Selain itu perhitungan besaran bunga harusnya didasarkan pada sisa pinjaman yang belum terbayar, bukan didasarkan pada pinjaman pokok. Setiap pengurangan pinjaman akibat dari anguran pokok perbulan mengharuskan berkurangnya besaran nominal bunga, dan dengan demikian prosentasi suku bunga yang disepakati dalam trasaksi berlaku secara konsisten. Hal yang demikian ini sebagaimana diberlakukan pihak lembaga keuangan (bank) dalam menghitung besaran nominal bunga tabungan dimana setiap pengurangan saldo tabungan, nominal bunga tabunganpun menjadi berkurang. Cara penghitungan bunga seperti ini baru adil namanya. Pemungutan bunga secara flat bisa dikatakan adil bilamana pola pelunasan pokok hutang tidak secara angsuran perbulan melainkn secara tunai di akhir masa perjanjian pinjaman.

Sebagai perbandingan, berikut ini disampaikan table bunga yang adil. Misalnya, aplikasi pinjaman sebesar Rp. 1.000.000 (Satu Juta Rupiah), suku bunga 1,5\% perbulan, diangsur 10 kali dalam 10 bulan. Nasabah setiap bulan mengangsur pokok pinjaman sebesar Rp.100.000 ditambah bunga sebesar $1,5 \%$ kali sisa pinjaman.

\footnotetext{
${ }^{23}$ Dalam bunga Flat ini biasanya pihak lembaga tidak mengijinkan perlunasan hutang sebelum jatuh tempo, karena akan mengurangi tingkat pengelembungan keuntungan lembaga.

${ }^{24}$ Selain yang telah disampaikan di muka, ada satu lagi ketidak-adilan dalam praktek lembaga keuangan, dimana perlunasan setoran sebelum jatuh tempo tidak berpengaruh terhadap nominal bunga. Misalnya jatuh tempo angsuran adalah tanggal 30. Lembaga pinjaman tetap memungut nominal bunga yang sama sekalipun peminjam menyetor angsuran pada tanggal 1 bulan jatuh tempo. Ini artinya 1 hari pinjaman dihitung 30 hari. Sebaliknya pihak lembaga pinjaman memungut bunga yang lebih besar dalam bentuk denda, bilamana peminjam menyetor angsuran sesudah tanggal jatuh tempo.
} 
Bunga pinjaman dalam perspektif keadilan

\begin{tabular}{|l|l|l|l|l|}
\hline Angsuran ke & Sisa Pinjaman & Angsuran Pokok & Suku bunga & Nom.bunga \\
\hline Angsuran I & Rp. 1.000 .000 & Rp. 100.000 & $1,5 \%$ & Rp. 15.000 \\
\hline Angsuran II & Rp. 900.000 & Rp. 100.000 & $1,5 \%$ & Rp. 13.500 \\
\hline Angsuran III & Rp. 800.000 & Rp. 100.000 & $1,5 \%$ & Rp.12.000 \\
\hline Angsuran IV & Rp 700.000 & Rp. 100.000 & $1,5 \%$ & Rp. 10500 \\
\hline Angsuran V & Rp. 600.000 & Rp. 100.000 & $1,5 \%$ & Rp. 9.000 \\
\hline Anghsuran VI & Rp. 500.000 & Rp. 100.000 & $1,5 \%$ & Rp.5.500 \\
\hline Angsuran VII & Rp. 400.000 & Rp. 100.000 & $1,5 \%$ & Rp. 6.000 \\
\hline Angsuran VIII & Rp. 300.000 & Rp. 100.000 & $1,5 \%$ & Rp.4.500 \\
\hline Angsuran IX & Rp. 200.000 & Rp. 100.000 & $1,5 \%$ & Rp. 3.000 \\
\hline Angsuran X & Rp. 100.000 & Rp. 100.000 & $1,5 \%$ & Rp. 1.500 \\
\hline Jumlah & & Rp. 1.000 .000 & & Rp. 80.500 \\
\hline
\end{tabular}

Dengan suku bunga yang konsisten sebesar 15\% atas pinjaman konkrit setelah pengangsuran pokok pinjaman terjadilah pengurangan nominal bunga yang terus bergerak kepada nominal bunga yang lebih kecil, sebagaimana terlihat dalam table di atas. Dalam suku bunga yang konsisten total nominal bunga sebesar Rp.80.500. Sedangkan dalam suku bunga yang tidak konsisten, sebegaimana terlihat dalam table sebelumnya, toal nominal bunga Rp. 150.000. Selisih antara keduanya sebesar Rp. 69.500 merupakan hasil penguasaan harta secara tidak syah melalui gharar(tipudaya).

Gharar selalu menguntungkan satu pihak dengan menjadikan pihak lain sebagai korban yang menanggung kerugian. Dampak negative gharar dalam penghitungan nominal bunga pinjaman di KPRI dalam konsep maqashid alsyariat tergolong mafashid, yakni situasi dan kondisi negative dan dampaknya yang menggangu atau menghambat penegakan keadilan dan kemaslahatan ummat. Kaidah maqshid al-syariah yang paling populer mengatakan bahwasanya "menyingkirkan mafashid diprioritaskan dari pada meraih masholeh". Berdasarkan kaidah iin, maka pola penghitungan bunga yang tidak konsisten di KPRI harus segera diformat-ulang,. 


\section{Bunga Pinjaman Dalam Konteks Keadilan Koperasi}

Yang membedakan lembaga keuangan koperasi dengan lembaga keuangan non koperasi, misalnya perbankan, adalah prinsip keanggotaan. Lembaga keuangan non koperasi dibentuk oleh para pemilik modal untuk melayani fungsi keuangan kepada masyarakat (nasabah), baik dalam fungsi investasi dalam bentuk produk simpanan dan tabungan, maupun dalam fungsi pembiayaan. Betapapun besarnya tabungan masyarakat yang dititipkan di dalam sebuah lembaga keuangan dan betapapun besarnya peran masyarakat dalam menggunakan jasa pimbiayaan, masyarakat tetap saja kedudukannya sebagai nasabah yang tidak berhak atas profit yang dihasilkan dalam menjalankan kedua fungsi keuangan tersebut. Semua hasil dan keuntungan mutlak milik pemegang saham perusahaan. Yang demikian ini merupakan corak dari sistim keuangan ekonomi kapitalisme. Yakni bahwasanya masyarakat tidak lebih dari sekedar mesin penggerak dan mesin pencetak keuntungan bagi para pemilik modal.

Koperasi didirikan dengan modal dari anggota, melalui simpanan pokok, simpanan wajib dan simpanan sukarela, dikelola untuk melayani kebutuhan anggota, baik kebutuhan konsumtif maupun kebutuhan produktif, dengan tujuan untuk meningkatkan kesejahteraan anggota. Tujuan peningkatan kesejahteraan anggota ini setidaknya bisa terwujud dalam dua hal. Pertama, di koperasi anggota bisa mendapatkan harga yang lebih murah. Sebab didalam koperasiasi, biaya operational menejemen dan marketing lebih ringan, sehingga margin keuntungan bisa ditekan lebih rendah.

Kedua, semua anggota berhak atas sisa hasil usaha koperasi. Di dalam koperasi, anggota yang melakukan transaksi berarti ia melakukan transaksi yang menguntungkan bagi dirinya sendiri, bukan menguntungkan kelompok pemodal. Jika koperasi tersebut tumbuh dan berkembang menjadi besar sama artinya dengan tumbuh dan berkembangnya kesejahteraan para anggota.

Pembagian SHU dari Unit simpan pinjam KPRI "Nusantara" dengan pola pembagian $40 \%$ untuk porsi modal dan $60 \%$ untuk transaksi pinjaman. Anggota yang melakukan transaki peminjaman disebut sebagai anggota aktif. Sedang anggota yang tidak melakukan transaksi pinjaman dalam setahun disebut sebagai anggota pasif. Anggota aktif mempunyai dua hak atas SHU, yakni hak SHU atas simpanan sebesar 40\% dan hak SHU atas transaksi sebesar 60\%. Sedang Anggota yang tidak aktif berhak atas SHU modal saja. ${ }^{25}$.

25 Pembagaian SHU ini merujuk pada ketentuan PP. No.9 Tahun 1995 pasal 13 ayat (1) poit a : "Sisa Hasil Usaha yang diuperoleh Koperasi Sim pan Pinjam setelah dikurangi dana cadagan, 
Bunga pinjaman dalam perspektif keadilan

Pola pembagian SHU secara adil dan berimbang ini, seharusnya tidak hanya diterapkan pada Unit simpan. Sekiranya sistim pembagian SHU ini diterapkan juga dalam unit usaha yang lainnya, tentu akan mendongkrak omset transaksi. Apalagi kalo diikuti kebijakan keharusan anggota berbelanja di koperasi melalui pemotongan gaji, baik sistim pra bayar atau pasca bayar, niscaya omset transaksi koperasi bertambah besar.

Fakta bunga pinjaman sebesar 1,5\% di KPRI Nusantara secara obyektif lebih rendah dibandingkan bunga pinjaman pada lembaga keuangan perbankan. Bunga rendah tersebut dipungut dari anggota melalui instrumen akad kredit (utang) dan pada akhirnya dibagikan kepada anggota melaui mekanisme pembagaian Sisa Hasil Usaha (SHU) secara adil dan berimbang. . Sistim pembagian SHU secara adil dan berimbang ini merupakan sisi positif dari unit simpan pinjam di KPRI Nusantara.

\section{Penutup}

Terciptanya tatanan kehidupan ekonomi-sosial yang berkeadilan yang berbingkai semangat keberpihakan dan kepedulian terhadap kelompok masyarakat lemah, sebagaimana disampaikan dalam konsep keadilan sosial John Rawls, sesungguhnya merupakan maqashid al-syariah dari sejumlah larangan keras al-Qur'an terhadap praktek riba Jahiliyah, perintah al-Qur'an terhadap kewajiban zakat dan shadaqah, seruan ajaran Islam terhadap tolong menolong dan seruan Islam terhadap prilaku adil dan kebajikan. Semua ini menjadi penguat bahwa pemungutan bunga di unit simpan pinjam KPRI Nusantara melalui transaksi pinjaman (akad qardh)) bertentangan dengan proyek besar Islam dalam membangun keadilan sosial ekonomi.

Ketidakadilan (zbulm) yang dalam paradigma kelompok modernist merupakan "raison d'etre" pengharaman riba terdapat dalam penghitungan nominal bunga di unit simpan pinjam KPRI Nusantara. Selain tidak adil $(d ₹ u l m)$, perhitungan nominal bunga mencerminkan ketidakkonsistenan antara prosentase bunga yang ditawarkan dengan nominal bunga yang dipungut. Bahkan keduanya (prosentasi bunga dan nominalnya) tidak dinyatakan di dalam kontrak perjanjian. Yang demikian ini merupakan praktek gharar .

dipergunakan untuk: (a) dibagika kepada anggota secara berimbang berdasarkan jumlah dana yang ditanamkan sebagai modal sendiri dan nilai transaksi. 
Dalam praktek gharar ini pihak lembaga (koperasi) memungut bunga dengan tidak fair, yakni tidak dinyatakan secara tegas dalam transaski, dan penghitungan jumlah nominal bunga yang dipungut didasarkan pada pola perhitungan yang tidak masuk akal. Pokok hutang berkurang tetapi nominal bunga tetap, seperti belum pernah mengangsur sama sekali.

Gharar selalu menguntungkan satu pihak dengan menjadikan pihak lain sebagai korban yang menanggung kerugian. Dampak negative gharar dalam penghitungan nominal bunga pinjaman di KPRI dalam konsep maqashid alsyari'at tergolong mafasbid, yakni situasi dan kondisi negative dan dampaknya bertentangan prinsip keadilan dan kemaslahatan ummat.

Satu hal yang mencerminkan keadilan sehubungan dengan praktek simpan pinjam di KPRI nusantara adalah sistim pembagian SHU. Dimana pembagiannya dengan pola proporsional: $40 \%$ untuk porsi modal, dan 60\% untuk porsi transaksi pinjaman. Anggota yang melakukan transaki peminjaman disebut sebagai anggota aktif. Sedang anggota yang tidak melakukan transaksi pinjaman dalam setahun disebut sebagai anggota pasif. Anggota aktif mempunyai dua hak atas SHU, yakni hak SHU atas simpanan sebesar 40\% dan hak SHU atas transaksi sebesar 60\%. Sedang Anggota yang tidak aktif berhak atas SHU modal saja.

Berdasarkan pembahasan dan penyimpulan sebagaimana telah disampaikan pada halaman halaman sebelumnya dan dalam rangka membangun sistem unit simpan pinjam yang adil berikut disampaikan beberapa saran.

1. Tentang Suku bunga pinjaman sebesar 1,5\%, hendaknya dipahami secara konsisten sebagai bunga, tidak dipahami sebagai imbalan jasa atau sebagai biaya adminitrasi. Bunga tersebut hendakanya dinyatakan secara jelas dalam point transaksi, kemudian penghitungan nominal bunga berdasarkan pada perkalian suku bunga terhadap hutang yang yang belum terbayar.

2. Hendaknya USP menyediakan pola pembiayaan lain selain utang-piutang sesuai dengan kebutuhan anggota dalam pengajuan pembiayaan. Sebagaimana diketahui ada dua kategori kebutuhan anggota, yakni kebutuhan konsumtif dan kebutuhan investasi. Pembiayaan untuk 
Bunga pinjaman dalam perspektif keadilan

kebutuhan konsumtif difasilitasi dengan pembiyaan pengadaan barang melalui akad murabah. Solusi ini secara ekonomi lebih menguntungkan bagi semua pihak dibandingkan dengan bunga pinjaman. Terutama menguntungkan anggota, karena mendapatkan harga pokok dan harga cicilan yang lebih murah dibandingkan dengan harga di luar koperasi. Sedangkan pembiyaan untuk kebutuhan investasi (usaha) difasilitasi dengan pola kerjasama melalui akad mudharabah. Solusi ini secara ekonomi juga memberikan keuntungan yang lebih prospektif kepada semua pihak.

3. Adalah sangat memungkinkan USP KPRI Nusantara melayani jasa pinjaman tanpa bunga yang dikenal sebagai "qardbul hasan" untuk kasus dengn kriteria tertentu di luar pembiayaan pengadaan barang dan investasi. Layanan qardhul hasan ini merjpakan aksi sosial dalam rangka keberpihakan dan kepedulian terhadap anggota yang kurang mampu. Maka dalam hal ini, menurut saya, pihak koperasi bisa bekerjasama dengan pengurus BKS IAIN Walisongo untuk mendistribusikan dana BKS, karena terkait dengan visi dan misi sosial BKS. 


\section{DAFTAR PUSTAKA}

Abdul Azis Dahlan ...(et.al), Ensiklopedi Hukum Islam, Jilid 5, Jakarta: PT. Ichtiar Baru van Hoeve, 1977

Adiwarman Karim, Ekonomi Makero Islam ,Jakarta: PT. RajaGrafindo Persada, 2007.

Andi Soemitro, Bank dan Lembaga kenangan syari'ah, Jakarta: PT. RajaGrafindo

Atang Abd. Hakim, Fiqib Perbankan Syariah (Transformasi Fiqib Muamalah ke dalam Peraturan Perundang-Undangan, Jakarat: PT Refika Aditama, 2011.

Carl Jochim Friedrich, Filsafat Hukum Perspektif Historis, Bandung: Nuansa dan Nusamedia, 2004

Cecep Maskanul Hakim, Belajar Mudah Ekonomi Islam (Catatan Kritis Terhadap Perkembangan Perbankan Syariah di Indonesia), Banten: Shuhuf Meia Insani, 2011

Fathur Rahman Djamil, Filsafat Hukum Islam, Bag. I, Jakarta: Logos Wacana Ilmu, 1997,

Dawam Rahardjo, Ensiklopedi al-Qur'an: Tafsir Sosial Berdasarkan konsepKonsep Kunci, Jakrata: ParaMadina, 2002

Fazlur Rahman, Tema Pokok al-Qur'an, terj.Anas Mahyuddin, Bandung: Pustaka, 1983

Ghufron Ajib Mas'adi, Fikih Muamalah kontekstual, Jakarta: PT Rajagrafindo Persada, 2002.

John Rawls, A Theory of Justice, London: Oxford University press, 1973, diterjemahkan dalam bahasa indonesia oleh Uzair Fauzan dan Heru Prasetyo, Teori Keadilan, Yogyakarta: Pustaka Pelajar, 2006

Kasmir, Bank dan Lembaga Keuangan Lainnya, Jakarta: PT. RajaGrafindo Persada, 2008

Masdar F. Mas'udi, "Meletakean Kembali Maslahat Sebagai Acuan Syari'ab" Jurnal Ilmu dan Kebudayaan Ulumul Qur'an No.3, Vol. VI Th. 1995

Volume IV/Edisi 1/Mei 2013 
Bunga pinjaman dalam perspektif keadilan

Moh. Nazir, Metode Penelitian, Jakarta: Ghalia Indonesia, t.th.

Muh. Zuhri, Riba Dalam al-Qur'an dan Masalah Perbankan (Sebuah Tilikan Antispatif), Jakarta: PT. Rajagrafindo Persada, 1997

Pandji Anoraga fdan Ninik Widiyhanti, Dinamika Koperasi, Jakarta, Rineka Cikta, 2007

Thamrin Abdullah dan Francis Tantri, Bank dan Lembaga Keuangan, Jakarta: PT RajaGarfindo Persada, 2012 